\title{
Which variables are associated with blood glucose levels outside the target range in surgical critically ill patients? A retrospective observational study
}

\author{
Manfred Weiss ${ }^{1 *}$, Martina Kron², Birgit Hay², Michael Taenzer ${ }^{1}$, Peter Radermacher ${ }^{1}$ and Michael Georgieff ${ }^{1}$
}

\begin{abstract}
Background: The aim of the present study is to determine the variables affecting blood glucose concentrations outside the target range of 80 and $150 \mathrm{mg} / \mathrm{dl}$ in critically ill surgical patients.

Methods: All critically ill surgical patients admitted to a university ICU, from 01/2007 to 12/2008, were surveyed daily using computer assistance with respect to minimal and maximal daily blood glucose concentrations, application of insulin and demographic/clinical variables. Multiple logistic regression for clustered data with backward elimination was performed to identify variables strongly associated with blood glucose concentrations $<80 \mathrm{mg} / \mathrm{dl}$ or $\geq 150 \mathrm{mg} / \mathrm{dl}$ in 804 patients with an ICU stay $>72$ hours.

Results: Application of insulin (odds ratio (OR) 2.1, with corresponding 95\% confidence interval (CI) 1.7; 2.6), noradrenaline (OR 1.4, 95\% Cl 1.2 - 1.8) or steroids (1.3, 1.003 - 1.7), and age (per year) (1.02, 1.01 - 1.03) were associated with an increased risk of blood glucose concentrations $<80 \mathrm{mg} / \mathrm{dl}$. In analogy, application of insulin (OR 2.4, 95\% Cl 2.0 - 2.7), noradrenaline (1.4, 1.2 - 1.6) or steroids (1.4, 1.2 - 1.7), severe sepsis (1.2, 1.1 - 1.4), neurosurgery (OR 1.0) compared to abdominal, vascular and trauma surgery, and age (per year) (1.01, 1.01 - 1.02), were associated with an increased risk of blood glucose concentrations $\geq 150 \mathrm{mg} / \mathrm{dl}$.

Conclusions: Critically ill surgical patients are at an increased risk for fluctuating blood glucose concentrations ranging $<80 \mathrm{mg} / \mathrm{dl}$ or $\geq 150 \mathrm{mg} / \mathrm{dl}$ in particular if they are of advanced age and require administration of insulin, noradrenaline, and/or steroids. Patients who underwent neurosurgery and/or presented with severe sepsis/shock are those in particular at risk for blood glucose concentrations $\geq 150 \mathrm{mg} / \mathrm{dl}$.
\end{abstract}

\section{Background}

In 2004 and 2008, the "Surviving Sepsis Campaign" (SSC) guidelines for the management of severe sepsis and septic shock were published to improve outcome of critically ill patients $[1,2]$. These guidelines recommend that patients with severe sepsis/septic shock and blood glucose concentrations $\geq 150 \mathrm{mg} / \mathrm{dl}$ receive IV insulin therapy to keep blood glucose levels in the range of 80 $150 \mathrm{mg} / \mathrm{dl}[1,2]$. A validated protocol for insulin dose adjustments was suggested targeting glucose levels of $<150 \mathrm{mg} / \mathrm{dl}[1,2]$.

Prophylactic perioperative intensive insulin therapy (IIT) reduced mortality and organ dysfunctions [3] in

\footnotetext{
* Correspondence: manfred.weiss@uniklinik-ulm.de

'Department of Anaesthesiology, University Hospital Medical School UIm,

Steinhoevelstr. 9, 89075 Ulm, Germany

Full list of author information is available at the end of the article
}

surgical patients, with a length of stay in the intensive care unit (ICU) of at least three days [4], but not in a combined population of medical/surgical patients [5], nor in patients with severe sepsis [6]. In contrast to the first two successful trials $[3,4]$, five randomized controlled trials showed no beneficial effects of strict glycemic control with intensive insulin therapy [5-8]. Some reasons for these contrasting observations are due to variability in the performance of strict glycemic control, differences among trial designs, changes in standard of care, time initiation of strict glycemic control, and the convergence between the intervention groups and control groups with respect to achieved blood glucose levels in the successive randomized controlled trials [7]. Large variability of blood glucose concentrations in IIT and control groups was considered as one possible explanation for the lack of beneficial effects of insulin therapy 
$[9,10]$. Moreover, patients with sepsis and increased glycemic lability index, but lower average glucose values, had an almost five-fold increased risk of hospital mortality (odds ratio $=4.73,95 \%$ confidence interval $=2.6-8.7$ ) [11]. It remained unclear whether the increased susceptibility to severe hypoglycemia (glucose level $\leq 40 \mathrm{mg} / \mathrm{dl}$ ) with intensive insulin therapy in sepsis patients was due to liver and renal dysfunction [6]. Taken together, recognizing predisposing factors for blood glucose concentrations $<80 \mathrm{mg} / \mathrm{dl}$ or $\geq 150 \mathrm{mg} / \mathrm{dl}$ might help in identifying patients at risk so that more intensive monitoring or less tight blood glucose targets could be used.

In this context, the following variables have been reported to be associated with increased risk for hypoglycemia or hyperglycemia: age [12,13], sex [12], type of surgery; severity of disease [14] and severe systemic inflammatory response syndrome (SIRS)/sepsis [15,16]; kidney [14,17], liver [17] and organ dysfunctions; application of steroids [13,18-21], adrenaline and/or noradrenaline infusion $[16,21,22]$. Nonetheless, it was unclear which of these factors are most responsible in hindering the efforts to maintain blood glucose levels in the range of $80-150 \mathrm{mg} / \mathrm{dl}$ as adviced by the SSC guidelines $[1,2]$. Therefore, the present study was performed in a surgical adult intensive care unit (ICU) in surgical critically ill patients with an ICU stay > 72 hours to answer the following questions:

1 . What is the frequency of observed blood glucose levels outside the target range of $80-150 \mathrm{mg} / \mathrm{dl}$ ?

2. Is age, gender, type of surgery, severity of disease, severity of organ dysfunctions, application of steroids, adrenaline, noradrenaline, steroids or insulin, and severe sepsis and shock associated with blood glucose concentrations $<80 \mathrm{mg} / \mathrm{dl}$ or $\geq 150 \mathrm{mg} / \mathrm{dl}$, respectively?

3. What factors are most responsible for blood glucose levels outside the target range?

\section{Methods}

\section{Patients and data collection}

The prospective study is in compliance with the Helsinki declaration and was approved by the Independent Ethics Committee of the University Ulm, which waived informed consent because this was an observational study, and no additional interventions were performed.

All surgical critically ill patients, from 01/2007 to $12 / 2008$, admitted to the Anesthesiology ICU of the University Hospital Ulm after major trauma, vascular, lung, brain and abdominal surgery were followed daily, computer assisted, for minimal and maximal blood glucose concentrations.

The following variables were documented on admission: age, sex, type of surgery (major trauma, vascular and lung, brain or abdominal surgery), and severity of disease by the Simplified Acute Physiology Score II (SAPS II) score [23].
The severity of the systemic inflammatory response syndrome (SIRS)/sepsis and shock (the 1992 American College of Chest Physicians/Society of Critical Care Medicine (ACCP/SCCM) consensus conference definitions [24] and the 2003 SCCM/ESICM/ACCP/ATS/SIS sepsis definitions [15]), acute kidney injury demanding extracorporeal renal support, liver dysfunction assessed by the Model of Endstage Liver Disease (MELD) score [25], organ dysfunctions reflected by the Sequential Organ Failure Assessement (SOFA) score [26], insulin administration, steroid, adrenaline and/or noradrenaline infusion, were monitored, computer-assisted, on a daily basis by the ICU residents and staff physicians. SIRS was defined by two or more of the four conditions: temperature, heart rate, respiratory rate, and white blood cell count (WBC) by the 1992 definitions. If SIRS was due to a documented infection, patients were classified as sepsis patients. Severe sepsis was defined as sepsis accompanied by organ dysfunction, i. e., defined as recommended [26] for the 1992 sepsis definitions, or greater than two points in one organ system using the SOFA score. Septic shock was defined as sepsis together with hypotension despite adequate fluid resuscitation. Sepsis was defined due to the 2003 definitions [15], if at least two out of the enlarged list of general and inflammatory variables were fulfilled, i.e., temperature, heart rate, respiratory rate, significant edema, positive fluid balance, hyperglycemia (plasma glucose $>120 \mathrm{mg} / \mathrm{dl}$ ), white blood cell count (WBC), and plasma C-reactive protein. Severe sepsis was defined as sepsis plus organ dysfunction according to the limitations for organ dysfunction variables and tissue perfusion variables (hyperlactatemia) given in the 2003 sepsis definitions publication [15]. The reason for the two sepsis definitions is that the frequency and mortality rates of various sepsis severity stages differ if defined by the 1992 or the 2003 definitions within the same patient population [27]. The 1992 definitions may under-classify patients with severe sepsis. Thus, transferring recommendations such as those of the SSC guidelines drawn from data sets regarding severity of sepsis generated with the 1992 definitions to the same population applying the 2003 definitions may be misleading. Therefore, in the present study, sepsis was defined using the original 1992 ACCP/SCCM [24] and the revised 2003 SCCM/ESICM/ACCP/ATS/SIS sepsis definitions [15]. In the 2003 definitions, hyperglycemia is defined as plasma glucose $>120 \mathrm{mg} / \mathrm{dl}$ in the absence of diabetes and is one of the general variables in the diagnostic criteria for sepsis. Therefore, we expected different subgroups of patients in our patient collective when defining sepsis with the 1992 or the 2003 definitions. Acute kidney injury was defined as urine output $<0.5 \mathrm{ml} / \mathrm{kg}$ for more than 2 hours [15], and/ or increase in creatinine $>44 \mathrm{umol} / \mathrm{l}$ [15] and/or extracorporeal renal support [15]. Hydrocortisone was used in adult septic shock according to the SSC guidelines $[1,2]$, 
i. e., after blood pressure was identified to be poorly responsive to fluid resuscitation and vasopressor therapy.

The following patients were excluded in the final evaluation: patients with unfavorable prognosis, patients $<18$ years (because SAPS II score [23] and the ACCP/ SCCM sepsis definitions [24] have been developed for patients $\geq 18$ years, and the SOFA score [26] for patients $\geq 12$ years), patients with insulin dependent diabetes mellitus, patients with previous diagnosis of diabetes mellitus, and patients with a stay $<72$ hours on the ICU in analogy to previous studies [4].

Routine blood glucose measurements were performed by a blood gas analyzer (Radiometer Copenhagen $\mathrm{GmbH}$, Willich, Germany) according to the guidelines of the "Surviving Sepsis Campaign" [1,2]. Thus, in our department, glucose measurements are performed routinely every $1-2 \mathrm{hrs}$ ( $4 \mathrm{hrs}$ when stable) in patients receiving intravenous insulin, and every 30 to $60 \mathrm{~min}$ utes in patients with glucose values $<80 \mathrm{mg} / \mathrm{dl}$. In severely ill patients without insulin administration, blood glucose was measured at least four times a day.

\section{Statistical analysis}

Data comprised clustered observations because of repeated measures taken during each patient's course in the ICU. Therefore, analyses of associations between blood glucose concentrations $<80 \mathrm{mg} / \mathrm{dl} /$ blood glucose concentrations $\geq 150 \mathrm{mg} / \mathrm{dl}$ and demographic/clinical variables were performed in a logistic regression adjusted for clustered observations.

In a first step, separately for each of the two outcome variables (blood glucose concentrations $<80 \mathrm{mg} / \mathrm{dl}$ vs $80-<150 \mathrm{mg} / \mathrm{dl}$, and blood glucose concentrations $\geq 150 \mathrm{mg} / \mathrm{dl}$ vs $80-<150 \mathrm{mg} / \mathrm{dl}$ ) and any of the explanatory variables, associations were assessed by logistic regression. Crude odd ratios (ORs) with 95\% confidence interval (CI) and p-values were calculated.

In a second step, for each outcome variable, the explanatory variables were assessed simultaneously, and relevant factors were identified by backward elimination in a multiple logistic regression.

\section{Results}

During the period dating from 01/2007 to 12/2008, 1637 postoperative/posttraumatic critically ill patients were admitted to the ICU. A total of 804 patients met the inclusion criteria with an ICU stay $>72$ hours and were eligible for final evaluation.

Baseline characteristics of these patients were as follows. The median of age was 65 (range $18-98$, mean 61.0, SD 17.1). Out of these 804 patients, 241 (30\%) were female, $84(10.5 \%)$ were non-survivors, $225(28 \%)$ were admitted due to neurosurgery, 217 (27\%) due to abdominal surgery, 193 (24\%) due to vascular surgery, and 169 (21\%) due to trauma surgery. The median SAPS II score on admission was 32 (range 6 - 82, mean 34.5, SD 15.9).

Characteristics during the course on the ICU were as follows. Insulin was applied in 642 (79.9\%) of the 804 patients, steroids in 265 (33.0\%), adrenaline in 191 (23.8\%), noradrenaline in $564(70.2 \%)$. Extracorporeal renal support was performed in $84(10.5 \%)$ patients. $478(60.0 \%)$ patients had severe SIRS/sepsis due to the 1992 definitions, and 705 (88.7\%) due to the 2003 definitions. The maximal MELD score was 7 in median (range -46 - 69, mean 9.6, SD 9.98). The maximal SOFA score was 6 in median (range 0 - 18, mean 6.5, SD 3.3).

Complete information regarding the daily minimal and maximal blood glucose concentrations, insulin administration, demographic/clinical variables and scores were available in 7409 observations in total, of these 2273 without and 5136 with insulin administration. The number of observations within distinct blood glucose ranges in all patients are presented in Table 1. Blood glucose concentrations $<80 \mathrm{mg} / \mathrm{dl}$ occured in $10.9 \%$ of our observations.

To identify variables strongly associated with blood glucose concentrations $<80 \mathrm{mg} / \mathrm{dl}$ or $\geq 150 \mathrm{mg} / \mathrm{dl}$, crude odds ratios (OR) with $95 \%$ confidence intervals (95\% CI) and p-values were calculated and are presented in Table 2. The variables associated with an increased risk of blood glucose concentrations $<80 \mathrm{mg} / \mathrm{dl}$ were: age, female sex, SAPS II > 36, MELD > 9, SOFA $>4$, application of adrenaline, noradrenaline, steroids or insulin. Those variables associated with an increased risk of blood glucose concentrations $\geq 150 \mathrm{mg} / \mathrm{dl}$ were: age, neurosurgery compared to all other types (abdominal, vascular, trauma surgery), SAPS II > 36, sepsis defined by the 1992 or the 2003 definitions, MELD > 9, SOFA > 4, and administration of adrenaline, noradrenaline, steroids or insulin.

Multiple logistic regression with backward elimination was performed to simultaneously assess and identify variables strongly associated with blood glucose concentrations $<80 \mathrm{mg} / \mathrm{dl}$ or $\geq 150 \mathrm{mg} / \mathrm{dl}$. Thereby, increasing age, application of noradrenaline, steroids or insulin were strongly associated with blood glucose concentrations $<80 \mathrm{mg} / \mathrm{dl}$ (Table 3). In addition to these variables,

Table 1 Distribution of the number of observations within various blood glucose ranges

\begin{tabular}{lcc}
\hline & \multicolumn{2}{c}{ Observations (all, $\mathbf{n}=\mathbf{7 , 4 0 9 )}$} \\
\hline Blood glucose $(\mathbf{m g} / \mathbf{d l})$ & 65 & $\%$ of all \\
\hline$<40$ & 122 & $0.9 \%$ \\
40 to $<60$ & 623 & $1.6 \%$ \\
60 to $<80$ & 3583 & $8.4 \%$ \\
80 to $<150$ & 3016 & $48.4 \%$ \\
$\geq 150$ & $60.7 \%$ \\
\hline
\end{tabular}

To convert the values for glucose to millimoles per litre, multiply by 0.05551 . 
Table 2 Crude OR $(95 \% \mathrm{Cl})$ of factors associated with blood glucose concentrations $<80 \mathrm{mg} / \mathrm{dl}$ or $\geq 150 \mathrm{mg} / \mathrm{dl}$

\begin{tabular}{|c|c|c|c|c|}
\hline & \multicolumn{2}{|c|}{$B G<80$ vs $80 \leq B G<150$} & \multicolumn{2}{|c|}{$B G \geq 150$ vs $80 \leq B G<150$} \\
\hline & OR $(95 \% \mathrm{Cl})$ & $P$ value & OR $(95 \% \mathrm{Cl})$ & $P$ value \\
\hline Age (per year) & $1.02(1.01 ; 1.03)$ & $<0.001$ & $1.02(1.01 ; 1.02)$ & $<0.001$ \\
\hline Gender (female vs male) & $1.4(1.1 ; 1.8)$ & 0.014 & $1.1(0.95 ; 1.4)$ & 0.148 \\
\hline Neurosurgery & 1.0 & 0.324 & 1.0 & $<0.001$ \\
\hline Abdominal surgery & $0.8(0.6 ; 1.1)$ & & $0.7(0.6 ; 0.9)$ & \\
\hline Vascular surgery & $0.8(0.6 ; 1.1)$ & & $0.7(0.6 ; 0.9)$ & \\
\hline Trauma surgery & $0.7(0.5 ; 1.03)$ & & $0.5(0.4 ; 0.7)$ & \\
\hline SAPS $\|(>36$ vs $\leq 36)$ & $1.5(1.2 ; 1.8)$ & $<0.001$ & $1.5(1.3 ; 1.7)$ & $<0.001$ \\
\hline Sepsis 1992 severe/shock (yes vs no) & $1.2(0.99 ; 1.4)$ & 0.068 & $1.4(1.2 ; 1.6)$ & $<0.001$ \\
\hline Sepsis 2003 severe/shock (yes vs no) & $1.1(0.9 ; 1.3)$ & 0.355 & $1.2(1.04 ; 1.3)$ & 0.012 \\
\hline Extracorporeal renal replacement therapy (yes vs no) & $1.3(0.9 ; 1.8)$ & 0.124 & $1.3(0.95 ; 1.7)$ & 0.103 \\
\hline MELD (>9 vs $\leq 9)$ & $1.3(1.1 ; 1.7)$ & 0.008 & $1.3(1.1 ; 1.5)$ & 0.005 \\
\hline SOFA (>4 vs $\leq 4)$ & $1.4(1.2 ; 1.7)$ & $<0.001$ & $1.5(1.3 ; 1.7)$ & $<0.001$ \\
\hline Adrenaline (yes vs no) & $1.7(1.9 ; 2.4)$ & 0.004 & $1.3(1.02 ; 1.6)$ & 0.031 \\
\hline Noradrenaline (yes vs no) & $1.7(1.4 ; 2.0)$ & $<0.001$ & $1.7(1.5 ; 2.0)$ & $<0.001$ \\
\hline Steroids (yes vs no) & $1.8(1.4 ; 2.2)$ & $<0.001$ & $2.0(1.7: 2.3)$ & $<0.001$ \\
\hline Insulin (yes vs no) & $2.4(1.9 ; 3.0)$ & $<0.001$ & $2.8(2.4 ; 3.2)$ & $<0.001$ \\
\hline
\end{tabular}

$\mathrm{BG}=$ blood glucose; $\mathrm{Cl}=$ confidence interval; IIT = intensive insulin therapy; MELD = model of end stage liver disease; OR = odds ratio; SAPS II = Simplified Acute Physiology Score; SOFA = Sequential Organ Failure Assessment.

Number of data sets: see Table 1. ORs with $p<0.05$ are highlighted in bold numbers.

To convert the values for glucose to millimoles per litre, multiply by 0.05551 .

For comparison with the other types of surgery, the risk has been set at 1 for neurosurgery.

neurosurgery compared to all other types of surgery, and sepsis as defined by the 1992 definitions were strongly associated with blood glucose concentrations $\geq 150 \mathrm{mg} / \mathrm{dl}$ (Table 3).

The relationship of clinical outcome and blood glucose concentrations $<80 \mathrm{mg} / \mathrm{dl}$ or $\geq 150 \mathrm{mg} / \mathrm{dl}$ is given in Table 4. Compared to patients with blood glucose levels always within the target range of 80 to $150 \mathrm{mg} / \mathrm{dl}$, patients with episodes of blood glucose concentrations $<80 \mathrm{mg} / \mathrm{dl}, \geq 150 \mathrm{mg} / \mathrm{dl}$, as well as $<80 \mathrm{mg} / \mathrm{dl}$ and $\geq$ $150 \mathrm{mg} / \mathrm{dl}$, in addition, revealed an increased risk of death $(\mathrm{p}=0.009)$.

\section{Discussion}

The present study reveals that the most relevant factors associated with blood glucose concentrations $<80 \mathrm{mg} /$ $\mathrm{dl}$ or $\geq 150 \mathrm{mg} / \mathrm{dl}$ are age and application of noradrenaline, steroids or insulin. In addition, neurosurgery and severe sepsis/shock are variables strongly associated with blood glucose concentrations $\geq 150 \mathrm{mg} / \mathrm{dl}$.

Patients who underwent neurosurgery and those in septic shock [1,2], are frequently treated with noradrenaline and steroids. In separate analyses of explanatory variables (Table 2), severe sepsis/septic shock was associated with increased risk of blood glucose concentrations $\geq 150 \mathrm{mg} / \mathrm{dl}$. Hyperglycemia, i. e. plasma glucose > $120 \mathrm{mg} / \mathrm{dl}$ in the absence of diabetes, is one of the broadened diagnostic criteria for sepsis in the 2003 definition. The frequencies of severe sepsis and septic shock were higher and mortality rates lower when the 2003 definitions (lower thresholds for the definition of organ dysfunctions [15]) were applied instead of the 1992 definitions although it was in the same population of critically ill surgical patients [27]. Elderly neurosurgical patients requiring noradrenaline to increase intracranial perfusion pressure and steroids to reduce edema and swelling, as well as elderly patients with more severe organ dysfunctions and in septic shock who were treated with noradrenaline and steroids according to the "Surviving Sepsis Campaign" guidelines [1,2] are at higher risk for blood glucose concentrations $\geq 150 \mathrm{mg} / \mathrm{dl}$.

In a recent meta-analysis, there was no survival benefit regarding tight glucose control with intensive insulin therapy (IIT) in all analyzed 13,567 patients (OR 0.93, $95 \%$ CI $0.83-1.04)$, however, in the subset of surgical patients (OR $0.63,95 \%$ CI $0.44-0.90)$ [8] there was a significant survival benefit. In the perioperative concept of IIT, the greatest reduction in mortality in surgical ICU patients with sepsis and receiving mechanical ventilation involved deaths due to multiple-organ failure [3]. In these patients with severe sepsis it was speculated that the higher rate of severe hypoglycemia in the IIT group [3] was due to renal or liver dysfunction [6]. In the present study, surgical patients with renal dysfunction assessed as extracorporeal renal replacement therapy were not associated with an increased risk of blood glucose concentrations $<80 \mathrm{mg} / \mathrm{dl}$ or $\geq 150 \mathrm{mg} / \mathrm{dl}$ (Table 2, 3). This is in contrast to medical-surgical ICU patients, where 
Table 3 Multiple logistic regression with backward elimination

\begin{tabular}{|c|c|c|c|c|}
\hline & \multicolumn{2}{|c|}{ BG $<80$ vs $80 \leq B G<150$} & \multicolumn{2}{|c|}{$B G \geq 150$ vs $80 \leq B G<150$} \\
\hline & OR $(95 \% \mathrm{Cl})$ & $P$ value & OR $(95 \% \mathrm{Cl})$ & $P$ value \\
\hline Age (per year) & $1.02(1.01 ; 1.03)$ & $<0.001$ & $1.01(1.01 ; 1.02)$ & $<0.001$ \\
\hline Gender (female vs male) & - & & - & \\
\hline Neurosurgery & - & & 1.0 & $<0.001$ \\
\hline Abdominal surgery & & & $0.6(0.5 ; 0.7)$ & \\
\hline Vascular surgery & & & $0.7(0.6 ; 0.9)$ & \\
\hline Trauma surgery & & & $0.6(0.5 ; 0.8)$ & \\
\hline SAPS II (>36 vs $\leq 36)$ & - & & - & \\
\hline Sepsis 1992 severe/shock (yes vs no) & - & & $1.2(1.1 ; 1.4)$ & 0.003 \\
\hline Sepsis 2003 severe/shock (yes vs no) & - & & - & \\
\hline Extracorporeal renal replacement therapy (yes vs no) & - & & - & \\
\hline MELD (>9 vs $\leq 9)$ & - & & - & \\
\hline SOFA (>4 vs $\leq 4)$ & - & & - & \\
\hline Adrenaline (yes vs no) & - & & - & \\
\hline Noradrenaline (yes vs no) & $1.4(1.2 ; 1.8)$ & $<0.001$ & $1.4(1.2 ; 1.6)$ & $<0.001$ \\
\hline Steroids (yes vs no) & $1.3(1.003 ; 1.7)$ & 0.047 & $1.4(1.2 ; 1.7)$ & $<0.001$ \\
\hline Insulin & $2.1(1.7 ; 2.6)$ & $<0.001$ & $2.4(2.0 ; 2.7)$ & $<0.001$ \\
\hline
\end{tabular}

OR $(95 \% \mathrm{Cl})$ of factors associated with blood glucose concentrations $<80 \mathrm{mg} / \mathrm{dl} \mathrm{or} \geq 150 \mathrm{mg} / \mathrm{dl}$.

$\mathrm{BG}=$ blood glucose; $\mathrm{Cl}=$ confidence interval; IIT = intensive insulin therapy; MELD = model of end stage liver disease; OR = odds ratio; SAPS II = Simplified Acute Physiology Score; SOFA = Sequential Organ Failure Assessment.

Number of data sets: see Table 1.

To convert the values for glucose to millimoles per litre, multiply by 0.05551 .

For comparison with the other types of surgery, the risk has been set at 1 for neurosurgery.

hemodialysis was a predictor of hypoglygemia [10] and renal insufficiency was an independent risk factor for severe hypoglycemia [14]. In the present study, severity of liver dysfunction was assessed by the MELD score and of organ dysfunctions by the SOFA score. In separate analyses (Table 2), a MELD score $>9$ and a SOFA score $>4$ were associated with a higher risk of blood glucose concentrations $<80 \mathrm{mg} / \mathrm{dl}$ or $\geq 150 \mathrm{mg} / \mathrm{dl}$, however, this association was not found by multiple logistic regression (Table 3). In medical-surgical ICU patients, female gender was one of the main predictors of hypoglycemia [10]. The higher risk of blood glucose concentrations $<80 \mathrm{mg} / \mathrm{dl}$ with age (Tables 2,3) and female gender (Table 2) in the present study are most probably due to an impaired counterregulatory response [12]. The higher risk of hypoglycemia may be due to the lower counterregulatory hormone threshold for hypoglycemia in women than in men, i. e., especially adrenaline, noradrenaline and growth hormone response
[12]. The association of blood glucose concentrations $<80 \mathrm{mg} / \mathrm{dl}$ with administration of noradrenaline and steroids was surprising. In a rat model of continuous endotoxin infusion resembling some of the metabolic and cardiovascular constellations of human sepsis, a decreased number of hepatic plasma membrane alpha 1-adrenergic receptors were found [28]. This might in part explain why a comparable subset of our patients might not have developed blood glucose concentrations $\geq 150 \mathrm{mg} / \mathrm{dl}$ but $<80$ $\mathrm{mg} / \mathrm{dl}$ in association with continuous noradrenaline infusion. On the other hand, hyperglycemia due to insulin resistance has been reported in human sepsis. Adipokine levels were extensively altered in patients with severe sepsis and shock [29]. Adiponectin, the prototype of an antiinflammatory and insulin-sensitizing adipocytokine, was diminished in these patients [29]. Out of the insulin-resistance mediating factors, plasminogen activator inhibitor-1 (PAI-1), MCP-1, IL-6, IL-8, IL-10 and tumour necrosis

Table 4 Blood glucose variability and outcome

\begin{tabular}{|c|c|c|c|c|}
\hline $80 \leq \mathrm{BG}<150(\mathrm{mg} / \mathrm{dl})$ & Total patients & Nonsurvivors (\%) & OR $(95 \% \mathrm{CI})$ & $P$ value \\
\hline always & 118 & $4(3.4 \%)$ & 1.0 & 0.009 \\
\hline plus BG $<80$ & 26 & $2(7.7 \%)$ & $2.4(0.4 ; 13.7)$ & \\
\hline plus $B G \geq 150$ & 450 & $45(10.0 \%)$ & $3.2(1.1 ; 9.0)$ & \\
\hline \multirow[t]{2}{*}{ plus $B G<80$ and $B G \geq 150$} & 210 & $33(15.7 \%)$ & $5.3(1.8 ; 15.4)$ & \\
\hline & 804 & $84(10.5 \%)$ & & \\
\hline
\end{tabular}

$\mathrm{BG}=$ blood glucose; $\mathrm{Cl}=$ confidence interval.

To convert the values for glucose to millimoles per litre, multiply by 0.05551 . 
factor (TNF)- $\alpha$ were significantly elevated in these patients. All significant changes were shifted in the same direction as in obese subjects and patients with type 2 diabetes. These results may help to explain insulin resistance in critically ill patients and patients with systemic inflammatory response syndrome. After diagnosis of severe sepsis and shock, serum adiponectin levels and hydrocortisone correlated positively with insulin demand, and noradrenaline demand negatively with male adiponectin levels [30]. Septic shock causes a massive dilation of the peripheral vascular system, promoted by inflammatory cytokines and microbial toxins. Thus, the dosages of noradrenaline needed to provide a sufficient mean arterial pressure can be used to assess the degree of deterioration of the circulation (Sequential Organ Failure Assessment, SOFA score) for severity of organ dysfunction [26]. Thus, an increase in noradrenaline demand may reflect a clinical situation with changes in adipokines resulting in insulin resistance. Taken together, these data in septic patients may explain why we observed a positive association of noradrenaline with blood glucose concentrations $\geq 150 \mathrm{mg} / \mathrm{dl}$. On the other hand, adipokine panels resulting in overwhelming insulin sensitivity might set patients at risk of blood glucose concentrations $<80 \mathrm{mg} / \mathrm{dl}$. In this constellation, we might get an association of steroid and noradrenaline treatment with blood glucose concentrations $<80 \mathrm{mg} / \mathrm{dl}$, which is not due to the effects of steroids or noradrenaline per se. The variables SAPS II $>36$, MELD > 9, and SOFA > 4 in the present study were associated with an increased risk of blood glucose concentrations $<80 \mathrm{mg} / \mathrm{dl}$ reflecting patients with greater severity of disease and organ dysfunctions. One third of our patients were neurosurgical patients. Neurosurgical patients are often treated with noradrenaline to increase intracranial perfusion pressure and steroids to reduce edema and swelling. Thus, the pathopysiological reasons and the underlying adipokine pattern during steroid or noradrenaline treatment in our heterogenous patient groups may differ profoundly. This might explain why we found noradrenaline and steroid treatment as risk factors for both, blood glucose concentrations $\geq 150 \mathrm{mg} / \mathrm{dl}$ and $<80 \mathrm{mg} / \mathrm{dl}$.

The blunted ability of neutrophils to adapt to physiological hyperinsulinemia in older people $(69+/-4$ years $)$ may compromise the anti-infective response [31], and may contribute to sepsis. Taken together, elderly female patients with extracorporeal renal replacement therapy and/or liver dysfunction, especially under IIT, may be at increased risk of hypoglycemia.

The "Surviving Sepsis Campaign" guidelines for the management of severe sepsis and septic shock recommended intensive insulin therapy (IIT) targeting of glucose levels to the $<150 \mathrm{mg} / \mathrm{dl}$ range $[1,2]$. In the present study, $48.4 \%$ of minimal and maximal blood glucose data sets per day were in the target range of 80 to $<150 \mathrm{mg} / \mathrm{dl}$
(Table 1). This is comparable with a previous study in a mixed medical-surgical ICU with strict glycemic control, in which less than $50 \%$ of patients were within the target range with a considerable overlap between the intensive and the standard insulin group [10]. In the present study, severity of disease was assessed by SAPS II score. In separate analysis only (Table 2), SAPS II was associated with increased risk for blood glucose concentrations $<80 \mathrm{mg} /$ $\mathrm{dl}$ or $\geq 150 \mathrm{mg} / \mathrm{dl}$, however, not in multiple logistic regression (Table 3 ). Severity of illness reflected by the APACHE II score was one of the factors associated with the development of severe hypoglycemia in medical, surgical, and cardiac ICU patients in multiple logistic regression $[10,14]$. Thus, the severity of disease may put patients at risk of not falling within the recommended target range of 80 to $150 \mathrm{mg} / \mathrm{dl}$ blood glucose concentration.

In the present study, the overall hypoglycemia rates observed with blood glucose concentrations $<40 \mathrm{mg} / \mathrm{dl}$ in $0.9 \%$ and $<80 \mathrm{mg} / \mathrm{dl}$ in $10.9 \%$ (Table 1 ) were low, furthermore the administration of insulin was associated with an increased risk of blood glucose concentrations $<80 \mathrm{mg} / \mathrm{dl}$ (OR 2.1; 95\% CI 1.7 - 2.6) (Table 3). A comparison with hypoglycemia rates in the literature is difficult since hypoglycemia rates with IIT might be related to differences in patient populations, severity of illness, protocols, blood glucose targets, definitions of hypoglycemia, proportion of diabetic patients, ICU length of stay or duration of therapy. For example, the rates of hypoglycemia $(\leq 40 \mathrm{mg} / \mathrm{dl}$ ) were $0.5 \%$ [5], $1.7 \%$ [32] and $2.7 \%$ [33] in the control group, and 6.8\% [5], 8.5\% [32], 8.7\% [33] and 16\% [10] in the IIT group, respectively, in mixed surgical/medical ICUs. Taken together, in a recent metaanalysis, IIT was associated with a high risk (OR 6.0, 95\% CI 4.5 - 8.5) for hypoglycemia < $40 \mathrm{mg} / \mathrm{dl}$ [8].

A comparison to patients with blood glucose levels always within the target range of 80 to $150 \mathrm{mg} / \mathrm{dl}$, patients with episodes of blood glucose concentrations < $80 \mathrm{mg} / \mathrm{dl}$, of $\geq 150 \mathrm{mg} / \mathrm{dl}$, or of both, revealed an increased risk of death (Table 4). It has been suggested that quadrupling the rate of severe hypoglycemia and doubling the mortality attributable to severe hypoglycemia would erase the survival benefit of IIT in medical, surgical, and cardiac patients [14]. It remains unclear, whether hypoglycemia is associated with worse outcome or is simply a marker of severity of illness [10]. Spontaneous hypoglycemia without insulin therapy might be even more dangerous, resulting in a 1.7 -fold increase in mortality [34], because it is often detected late, furthermore, the duration of the episodes are longer due to less frequent monitoring than with IIT.

Thus, it is of high clinical relevance to know that beyond insulin therapy, the most relevant factors associated with hypoglycemia were noradrenaline infusion, 
steroids and age (Table 3). To prevent deleterious hypoglycemia, a higher target range of 140 - 180 instead of $<150 \mathrm{mg} / \mathrm{dl}$ in critically ill patients was recently suggested $[35,36]$.

The strengths of our study are that our ICU has a high nursing staff to patient ratio and is operated 24/7 by an on-site Critical Care Board-certified intensivist, and that intervention-related risk factors for blood glucose concentrations $\geq 150 \mathrm{mg} / \mathrm{dl}$ were evaluated. On the other hand, our study has several limitations. It is a single center trial. Other factors include adherence to the intensive insulin therapy protocol, the frequency of glucose measurements, the amount of average calories/day, the insulin dose, and the small number of hypoglycemic episodes $<40 \mathrm{mg} / \mathrm{dl}$, however most of the aforementioned limitations apply to many of the recently published studies concerning IIT as well.

\section{Conclusions}

The present study shows that the most relevant factors for blood glucose concentrations $<80 \mathrm{mg} / \mathrm{dl}$ in critically ill surgical patients were age, administration of noradrenaline, steroids and insulin. The most relevant factors for blood glucose concentrations $\geq 150 \mathrm{mg} / \mathrm{dl}$ were age, neurosurgery, severe sepsis/shock as defined by the 1992 definitions, steroids, noradrenaline and insulin. Thus, physicians and nurses have to be alert to these factors to avoid blood glucose concentrations $<80 \mathrm{mg} / \mathrm{dl}$ or hypoglycemia induced harm, especially in subgroups of patients with a combination of these most relevant factors.

\footnotetext{
Acknowledgements

We thank all the residents and staff physicians for the routine data acquisition in daily scoring of the patients. In addition, we thank Mr. Oscar McCook as a native speaker for language editing.
}

\section{Author details}

'Department of Anaesthesiology, University Hospital Medical School UIm, Steinhoevelstr. 9, 89075 Ulm, Germany. ${ }^{2}$ Institute of Epidemiology and Medical Biometry, University UIm, Schwabstr. 13, 89075 UIm, Germany.

\section{Authors' contributions}

MW, MK, BH, PR and MG participated in study conception, study design, data analysis, interpretation and drafting of the manuscript.

MT and MW participated in programming the computer-assisted scoring systems and data base, data acquisition, data analysis and interpretation of the manuscript.

All authors read and approved the final manuscript.

\section{Competing interests}

The authors declare that they have no competing interests.

Received: 23 December 2010 Accepted: 6 April 2011

Published: 6 April 2011

\section{References}

1. Dellinger RP, Carlet JM, Masur H, Gerlach H, Calandra T, Cohen J, GeaBanacloche J, Keh D, Marshall JC, Parker MM, Ramsay G, Zimmerman JL, Vincent $J$, Levy MM: Surviving Sepsis Campaign guidelines for management of severe sepsis and septic shock. Intensive Care Med 2004, 30(4):536-555.

2. Dellinger RP, Levy MM, Carlet JM, Bion J, Parker MM, Jaeschke R, Reinhart K, Angus DC, Brun-Buisson C, Beale R, Calandra T, Dhainaut JF, Gerlach H, Harvey M, Marini JJ, Marshall J, Ranieri M, Ramsay G, Sevransky J, Thompson BT, Townsend S, Vender JS, Zimmerman JL, Vincent JL: Surviving Sepsis Campaign: international guidelines for management of severe sepsis and septic shock: 2008. Intensive Care Med 2008, 34(1):17-60.

3. van den Berghe $G$, Wouters $P$, Weekers F, Verwaest $C$, Bruyninckx $F$, Schetz M, Vlasselaers D, Ferdinande P, Lauwers P, Bouillon R: Intensive insulin therapy in the critically ill patients. N Engl J Med 2001, 345(19):1359-1367.

4. Van den Berghe G, Wilmer A, Hermans G, Meersseman W, Wouters PJ, Milants I, Van Wijngaerden E, Bobbaers H, Bouillon R: Intensive insulin therapy in the medical ICU. N Engl J Med 2006, 354(5):449-461.

5. Finfer S, Chittock DR, Su SY, Blair D, Foster D, Dhingra V, Bellomo R, Cook D, Dodek P, Henderson WR, Hebert PC, Heritier S, Heyland DK, McArthur C, McDonald E, Mitchell I, Myburgh JA, Norton R, Potter J, Robinson BG, Ronco JJ: Intensive versus conventional glucose control in critically ill patients. N Engl J Med 2009, 360(13):1283-1297.

6. Brunkhorst FM, Engel C, Bloos F, Meier-Hellmann A, Ragaller M, Weiler N, Moerer O, Gruendling M, Oppert M, Grond S, Olthoff D, Jaschinski U, John S, Rossaint R, Welte T, Schaefer M, Kern P, Kuhnt E, Kiehntopf M, Hartog C, Natanson C, Loeffler M, Reinhart K: Intensive insulin therapy and pentastarch resuscitation in severe sepsis. N Engl J Med 2008, 358(2):125-139.

7. Schultz MJ, Harmsen RE, Spronk P: Clinical review: strict or loose glycemic control in critically ill patients - implementing the best available evidence from randomized controlled trials. Crit Care 2010, 14(223)

8. Griesdale DE, de Souza RJ, van Dam RM, Heyland DK, Cook DJ, Malhotra A, Dhaliwal R, Henderson WR, Chittock DR, Finfer S, Talmor D: Intensive insulin therapy and mortality among critically ill patients: a metaanalysis including NICE-SUGAR study data. CMAJ 2009, 180(8):821-827.

9. Egi M, Bellomo R, Stachowski E, French CJ, Hart G: Variability of blood glucose concentration and short-term mortality in critically ill patients. Anesthesiology 2006, 105(2):244-252

10. Arabi YM, Tamim HM, Rishu AH: Hypoglycemia with intensive insulin therapy in critically ill patients: predisposing factors and association with mortality. Crit Care Med 2009, 37(9):2536-2544.

11. Ali NA, O'Brien JM Jr, Dungan K, Phillips G, Marsh CB, Lemeshow S, Connors AF Jr, Preiser JC: Glucose variability and mortality in patients with sepsis. Crit Care Med 2008, 36(8):2316-2321.

12. Diamond MP, Jones T, Caprio S, Hallarman L, Diamond MC, Addabbo M Tamborlane W, Sherwin RS: Gender influences counterregulatory hormone responses to hypoglycemia. Metabolism 1993, 42(12):1568-1572.

13. Cely CM, Arora P, Quartin AA, Kett DH, Schein RM: Relationship of baseline glucose homeostasis to hyperglycemia during medical critical illness. Chest 2004, 126(3):879-887.

14. Krinsley JS, Grover A: Severe hypoglycemia in critically ill patients: risk factors and outcomes. Crit Care Med 2007, 35(10):2262-2267.

15. Levy MM, Fink MP, Marshall JC, Abraham E, Angus D, Cook D, Cohen J, Opal SM, Vincent JL, Ramsay G: 2001 SCCM/ESICM/ACCP/ATS/SIS International Sepsis Definitions Conference. Intensive Care Med 2003, 29(4):530-538.

16. Atkinson M, Worthley LI: Nutrition in the critically ill patient: part I. Essential physiology and pathophysiology. Crit Care Resusc 2003, 5(2):109-120.

17. Vriesendorp TM, van Santen S, DeVries JH, de Jonge E, Rosendaal FR, Schultz MJ, Hoekstra JB: Predisposing factors for hypoglycemia in the intensive care unit. Crit Care Med 2006, 34(1):96-101.

18. Watters JM, Bessey PQ, Dinarello CA, Wolff SM, Wilmore DW: Both inflammatory and endocrine mediators stimulate host responses to sepsis. Arch Surg 1986, 121(2):179-190.

19. Loisa P, Parviainen I, Tenhunen J, Hovilehto S, Ruokonen E: Effect of mode of hydrocortisone administration on glycemic control in patients with septic shock: a prospective randomized trial. Crit Care 2007, 11(1):R21.

20. Weber-Carstens S, Deja M, Bercker S, Dimroth A, Ahlers O, Kaisers U, Keh D: Impact of bolus application of low-dose hydrocortisone on glycemic control in septic shock patients. Intensive Care Med 2007, 33(4):730-733.

21. Gearhart MM, Parbhoo SK: Hyperglycemia in the critically ill patient. AACN Clin Issues 2006, 17(1):50-55. 
22. Reinelt $H$, Radermacher $P$, Kiefer $P$, Fischer $G$, Wachter $U$, Vogt $J$, Georgieff M: Impact of exogenous beta-adrenergic receptor stimulation on hepatosplanchnic oxygen kinetics and metabolic activity in septic shock. Crit Care Med 1999, 27(2):325-331.

23. Le-Gall JR, Lemeshow S, Saulnier F: A new Simplified Acute Physiology Score (SAPS II) based on a European/North American multicenter study. JAMA 1993, 270(24):2957-2963.

24. Bone RC: American College of Chest Physicians/Society of Critical Care Medicine Consensus Conference: Definitions for sepsis and organ failure and guidelines for the use of innovative therapies in sepsis. Critical Care Medicine 1992, 20:864-874.

25. Kamath PS, Wiesner RH, Malinchoc M, Kremers W, Therneau TM Kosberg CL, D'Amico G, Dickson ER, Kim WR: A model to predict survival in patients with end-stage liver disease. Hepatology 2001, 33(2):464-470.

26. Vincent JL, de Mendonca A, Cantraine F, Moreno R, Takala J, Suter PM, Sprung $\mathrm{CL}$, Colardyn F, Blecher S: Use of the SOFA score to assess the incidence of organ dysfunction/failure in intensive care units: results of a multicenter, prospective study. Working group on "sepsis-related problems" of the European Society of Intensive Care Medicine. Crit Care Med 1998, 26(11):1793-1800.

27. Weiss M, Huber-Lang M, Taenzer M, Traeger K, Altherr J, Kron M, Hay B, Schneider M: Different patient case mix by applying the 2003 SCCM/ ESICM/ACCP/ATS/SIS sepsis definitions instead of the 1992 ACCP/SCCM sepsis definitions in surgical patients: a retrospective observational study. BMC Med Inform Decis Mak 2009, 9:25.

28. Roth BL, Spitzer JA: Altered hepatic vasopressin and alpha 1-adrenergic receptors after chronic endotoxin infusion. Am J Physiol 1987, 252(5 Pt 1): E699-702.

29. Hillenbrand $A$, Knippschild $U$, Weiss M, Schrezenmeier $H$, Henne-Bruns $D$, Huber-Lang M, Wolf AM: Adipose tissue derived hormones in septic patients. BMC Surgery 2010, 10:26.

30. Hillenbrand A, Weiss M, Knippschild U, Stromeyer HG, Henne-Bruns D, Huber-Lang M, Wolf AM: Association of adiponectin levels and insulin demand in critically ill patients. Diabetes, Metabolic Syndrome and Obesity: Targets and Therapy 2011, 4:45-51.

31. Walrand S, Guillet C, Boirie Y, Vasson MP: Insulin differentially regulates monocyte and polymorphonuclear neutrophil functions in healthy young and elderly humans. J Clin Endocrinol Metab 2006, 91(7):2738-2748.

32. De La Rosa Gdel C, Donado JH, Restrepo AH, Quintero AM, Gonzalez LG, Saldarriaga NE, Bedoya M, Toro JM, Velasquez JB, Valencia JC, Arango CM, Aleman PH, Vasquez EM, Chavarriaga JC, Yepes A, Pulido W, Cadavid CA: Strict glycaemic control in patients hospitalised in a mixed medical and surgical intensive care unit: a randomised clinical trial. Crit Care 2008, 12(5):R120.

33. Preiser JC, Devos P, Ruiz-Santana S, Melot C, Annane D, Groeneveld J, lapichino G, Leverve X, Nitenberg G, Singer P, Wernerman J, Joannidis M, Stecher A, Chiolero R: A prospective randomised multi-centre controlled trial on tight glucose control by intensive insulin therapy in adult intensive care units: the Glucontrol study. Intensive Care Med 2009, 35(10):1738-1748.

34. Van den Berghe G, Wilmer A, Milants I, Wouters PJ, Bouckaert B, Bruyninckx F, Bouillon R, Schetz M: Intensive insulin therapy in mixed medical/surgical intensive care units: benefit versus harm. Diabetes 2006, 55(11):3151-3159.

35. Rabinstein AA: Hyperglycemia in critical illness: lessons from NICESUGAR. Neurocrit Care 2009, 11(1):131-132.

36. Bellomo R, Egi M: What is a NICE-SUGAR for patients in the intensive care unit? Mayo Clin Proc 2009, 84(5):400-402.

doi:10.1186/1754-9493-5-5

Cite this article as: Weiss et al: Which variables are associated with blood glucose levels outside the target range in surgical critically ill patients? A retrospective observational study. Patient Safety in Surgery 2011 5:5.

\section{Submit your next manuscript to BioMed Central and take full advantage of:}

- Convenient online submission

- Thorough peer review

- No space constraints or color figure charges

- Immediate publication on acceptance

- Inclusion in PubMed, CAS, Scopus and Google Scholar

- Research which is freely available for redistribution 